\title{
PENINGKATAN KEMAMPUAN MENGERJAKAN OPERASI HITUNG PENJUMLAHAN DAN PENGURANGAN MENGGUNAKAN METODE DEMONSTRASI DAN MEDIA BATU KRIKIL KECIL PADA SISWA KELAS 1 SD NEGERI AIKJA
}

\author{
MUHLIS \\ Guru Sdn Aikja Lombok Tengah, muhlishj@gmail.com
}

\author{
INFO ARTIKEL \\ Riwayat Artikel: \\ Diterima: 06-03-2018 \\ Disetujui: 27-03-2018

\section{Kata Kunci:} \\ Kemampuan \\ Hitung,Penjumlahan, \\ Pengurangan, \\ Metode Demonstrasi, \\ Media
}

\begin{abstract}
ABSTRAK
Abstrak: Penelitian Tindakan Kelas dua siklus dengan tujuan penelitian ini untuk meningkatkan kemampuan mengerjakan operasi hitung penjumlahan dan pengurangan menggunakan metode demonstrasi dan media batu kerikil pada siswa kelas 1 SDN Aikja Lombok Tengah 2016/2017". Hasil penelitian, bahwa kemampuan pada pra siklus dengan jumlah kelas 1sebanyak 20 diperoleh $40 \%$ atau 8 orang siswa meningkat 30\% menjadi $70 \%$ pada siklus I dan pada siklus II terjadi peningkatan sebanyak 20\% yaitu mencapai $90 \%$. Kesimpulan bahwa melalui metode demonstrasi dan media batu kerikil dapat meningkatkan kemampuan mengerjakan hitung penjumlahan dan pengurangan pada pembelajaran matematika di kelas I SDN Aikja tahun 2016/2017.
\end{abstract}

\begin{abstract}
The purpose of this research is to improve the ability to perform sum and reduction counting operation using demonstration method and small gravel stone media in grade 1 students of SDN Aikja Kab. Central Lombok Year 2016/2017 ". The research was conducted by using stages in Classroom Action Research (PTK), that is planning, implementation, observation, and refleksi.Penelitian conducted in two cycles, based on the description of the implementation of the action, research results, and discussion, obtained data on the improvement of the ability to do the count in every cycle. The ability of pre cycle with the number of classes 1sebanyak 20 obtained $40 \%$ or 8 students increased $30 \%$ to $70 \%$ in cycle I and on the second cycle there was an increase of $20 \%$ reaching $90 \%$. The conclusion that through demonstration method and small pebble media can improve the ability to work out the sum and subtraction of mathematics learning in class I SDN Aikja in the academic year 2016/2017.
\end{abstract}

\section{A. LATAR BELAKANG}

Matematika kerap kali dijadikan suatu mata pelajaran yang dianggap menakutkan, Gurupun dibuat pusing ketika berhadapan dengan siswa yang memang memilikikemampuan yang kurang dalam penjumlahan maupun pengurangan. Guru mau mengajar dengan metode apa yang memungkinkan siswa cepat memahami konsep penjumlahan maupun siswa mampu operasi penjumlahan.Hal inilah yang membuat guru merasa kesulitan dalam membimbing siswa. Disisi yang sangat penting, Pembelajaran hitung menghutung sebagai dasar pembelajaran yang sebagai salah satu mata pelajaran di sekolah dinilai sangat memegang peranan penting karena matematika dapat meningkatkan pengetahuan siswa dalam berpikir secara logis, rasional, kritis, cermat, efektif, dan efisien. Oleh karena itu, pengetahuan matematika harus dikuasai sedini mungkin oleh para siswa. Pentingnya siswa kelas 1 SD mempelajari operasi hitung penjumlahan dan pengurangan adalah sebagai awal dalam meneruskan jenjang tingkat berfikir dan untuk mmodal melanjutkan kep pendidikan yang lebih tinggi. Karena matematika merupakan pelajaran yang bersifat hierarki maka setiap sub bab yang ada akan sangat berkaitan dengan sub bab berikutnya. Untuk itu siswa kelas 1 harus benar-benar mampu menguasai operasi hitung penjumlahan dan pengurangan sebagai dasar awal untuk mempelajari materi matematika selanjutnya.

Kondisi nyata yang terjadi sekarang terkait hasil belajar siswa anak kelas 1 SD di SDN Aikja tentang operasi hitung penjumlahan dan pengurangan kurang. Letak dari SDN Aikja yang berada di pedalaman kampung yang minat belajar kurang berdampak pada kemampuan menangkap pelajaran rendah. Fokus pada penjumlahan dan pengurangan siswa kelas 1 di SDN Aikja tergolong kurang, terbukti dari 20 siwa hanya ada $40 \%$ atau sekitar 8 siswa yang mampu mengerjakan hitung penjumlahan dan pengurangan. Hal ini terlihat saat proses pembelajaran berlangsung anak itu terlihat bosan, cenderung pasif dan tidak semangat dalam belajar. Perbaikan sudah dilakukan tetap saja belum mendapat hasil yang maksimal.Salah satu penyebab masalah yang seperti ini adalah guru belum menggunakan media dan metode yang tepat yang sesuai dengan keadaan siswa sehingga siswa dalam pembelajaran terlihat pasif, gaduh, dan kurang motivasi.Kebanyakan proses pembelajaran yang digunakan adalah pembelajaran konvensional yakni ceramah, tanya jawab dan pemberian tugas sehingga pembelajaran didominasi oleh guru. 
Untuk menyampaikan materi dan dengan mudah di pahami oleh siswa diperlukan metode dan media yang tepat dalam pembelajaran.Siswa kelas I Sekolah Dasar masih tahap belajarnya pada fase operasional benda konkrit, karena itu media batu kerikil kecil dan metode demonstrasi adalah salah satu metode yang dapat di terapkan dalam pembelajaran di kelas 1 di SDN Aikja.

Menurut Muhibin syah (dalam Adrian,2004:8) metode demonstrasi adalah metode mengajar dengan cara memperagakan barang, dan urutan melakukan suatu kegiatan, baik secara langsung maupun melalui penggunaan media pengajaran yang relevan dengan pokok bahasan atau materi yang sedang disajikan. Media atau alat bantu sebagai komponen yang berasal dari lingkungan sekitar siswa,yang dapat memotivasi siswa untuk belajar dan sebagai alat yang digunakan untuk memberikan rangsangan bagi siswa agar terjadi proses belajar. Manfaat media dalam proses pembelajaran adalah memperlancar interaksi antara guru dengan siswa. Sehingga kegiatan pembelajaran akan lebih efektif dan efisien (Rahadi:2004).

Bertitik tolak dari latar belakang masalah di atas maka penulis mencoba melakukan penelitian yang berjudul:"Peningkatan Kemampuan Mengerjakan operasi Hitung Penjumlahan dan Pengurangan Menggunakan Metode Demonstrasi dan Media Batu kerikil kecil pada Siswa Kelas 1 SD Negeri Aikja Tahun 2016/2017". Tujuan Khusus dari penelitian ini adalah Meningkatkan kemampuan siswa dalam mengerjakan penjumlahan dan pengurangan pada pelajaran matematika kelas satu di SDN Aikja.

\section{B. METODE PENELITIAN}

Penelitian perbaikan pembelajaran ini dilaksanakan di SD Negeri Aikja kecamatan Praya Kabupaten Lombok Tengah. Penelitian dilaksanakan pada bulan januari 2017. Penelitian dilaksanakan di kelas I SD Negeri Aikja, Kecamatan Praya, Kabupaten Lombok Tengah. Pelaksanan penelitian dilaksanakan 2 siklus dan setiap siklus dilaksanakan 4 tahap kegiatan, yaitu perencanaan,pelaksanaan, pengamatan, dan refleksi. Sebelum penelitian dilaksanakan peneliti melakukan tindakan prasiklus, antara lain dengan menggunakan pembelajaran biasa yang dilaksanakan guru dengan pola menjelaskan tanpa penggunaan media aktivitas guru dan siswa dan hasil belajar yang diperoleh siswa.

Jenis data yang didapatkan dalam penelitian ini adalah data kuantitatif dan data kualitatif. Data kuantatif berupa nilai hasil belajar siswa dengan rentang nilai 0 sampai 100 . Nilai tersebut diperoleh dari hasil tes formatif yang dikerjakan siswa pada setiap siklus. Nilai hasil belajar siswa selanjutnya dirata-rata untuk menemukan rata-rata keberhasilan siswa secara klasikal. Data kualitatif berupa deskripsi hasil observasi terhadap aktivitas siswa pada saat melaksanakan pembelajaran, selain itu data kualitatif berupa lembar observasi pelaksanaan pembelajaran yang dilaksanakan dengan menerapkan metode demonstrasi dan penggunaan media batu krikil kecil. Tehnik pengumpulan data dalam PTK ini dilaksanakan dengan dua cara tes dan nontes. Tes formatif dilaksanakan untuk mengukur tingkat kemampuan mengerjakan hitung penjumlahan dan pengurangan siswa dalam pembelajaran matematika. Nontes dilaksanakan dengan menggunakan lembar observasi yang dilaksanakan mengamati kegiatan pembelajaran siswa dengan metode demonstrasi dan penggunaan media batu kerikil kecildalam pembelajaran matematika tentang penjumlahan dan pengurangan.

Alat pengumpulan data dalam PTK yang dilaksanakan adalah butir soal dan lembar observasi. Pengecekan keabsahan data dilakukan dengan memadukan hasil observasi, hasil-hasil catatan dari pengamat beserta evaluasi yang dilakukan untuk menjaga keabsahan data perlu dilakukan diskusi-diskusi dengan pengamat sehingga kesimpulan yang diperoleh sangat tepat sesuai. Untuk memperoleh data yang valid mengenai kemampuan mengerjakan hitung pada siswa kelas I SD Negeri Aikja yaitu: kemampuan mengerjakan operasi hitung penjumlahan dan pengurangan divalidasi melalui trianggulasi sumber yaitu menguji kredibilitas data yang dilakukan dengan cara mengecek data yang telah diperoleh melalui beberapa sumber dan untuk memperoleh data yang valid mengenai penggunaan media batu kerikil kecil divalidasi dengan Triangulasi Teknik yaitu menguji kredibilitas data yang dilakukan dengan cara mengecek data kepada sumber yang sama dengan teknik yang berbeda. Melalui PTK ini dalam menggunakan metode demonstrasi kemampuan siswa dalam mengerjakan operasi hitung penjumlahan dan pengurangan di harapkan akan meningkat. Siswa lebih aktif dalam pembelajaran dan guru lebih bervariasi dalam menggunakan metode pembelajaran. Penelitian ini berhasil apabila kemampuan siswa dalam mengerjakan operasi hitung penjumlahan dan pengurangan meningkat $70 \%$ pada siklus 1, dan 90\% pada siklus II. Kinerja guru dalam penerapan metode demonstrasi dan media batu kerikil kecil meningkat $70 \%$ pada siklus 1 , dan $90 \%$ pada siklus II.

\section{HASIL DAN PEMBAHASAN}

\section{SIKLUS 1}

Pelaksanaan penelitian pada siklus pertama diamati oleh kolaborant dengan menggunakan lembar observasi yang digunakan untuk mengamati pelaksanaan pembelajaran, baik kegiatan siswa maupun kegiatan guru.Hasil pengamatan pada kegiatan siswa difokuskan pada kemampuan siswa dalam mengerjakan operasi hitung melalui media.Dari hasil observasiyang dilakukan pada siklus I menunjukan adanyan peningkatan kemampuan mengerjakan operasi hitung penjumlahan dan pengurangan yaitu $70 \%$ sudah terampil dan $30 \%$ masih kurang terampil atau tergolong rendah, dapat dilihat pada tabel berikut ini :

TABEL 1.

HASIL OBSERVASI KEMAMPUAN MENGERJAKAN OPERASI HITUNG PENJUMLAHAN DAN PENGURANGAN PADA SIKLUS 1

\begin{tabular}{|l|l|l|}
\hline \multicolumn{1}{|c|}{ Prosent } & \multicolumn{1}{|c|}{ Kriteria } & Jumlah \\
\hline $1 \%-20 \%$ & Sangat Rendah & 0 \\
\hline $21 \%-40 \%$ & Rendah & 6 \\
\hline $41 \%-60 \%$ & Cukup & 5 \\
\hline $61 \%-80 \%$ & Tinggi & 7 \\
\hline $81 \%-100 \%$ & Sangat Tinggi & 2 \\
\hline
\end{tabular}




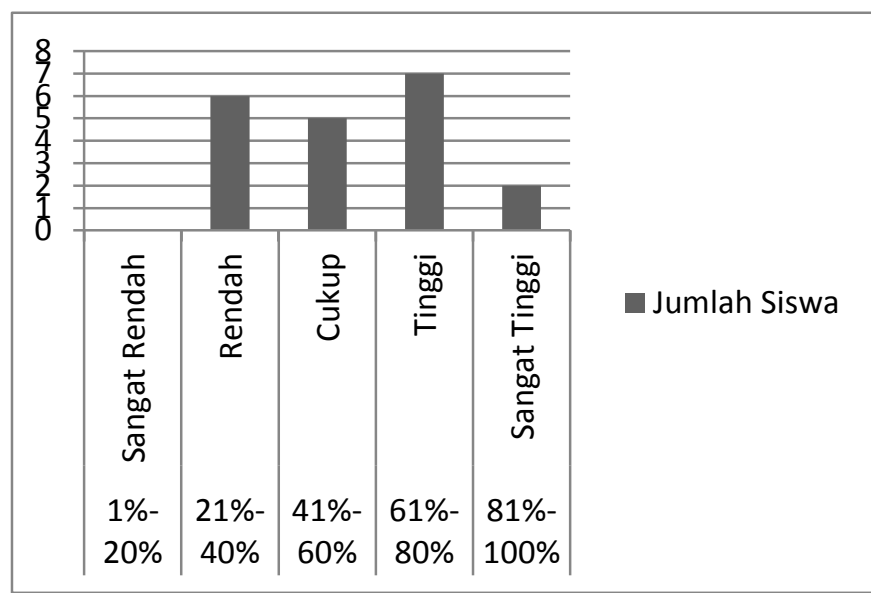

Gambar 1. Grafik Prosentase Kemampuan Mengerjakan operasi Hitung penjumlahan dan pengurangan siklus I

Dari hasil observasi pada siklus I $70 \%$ siswa sudah mampu mengerjakan yaitu 14 siswa dan $20 \%$ yaitu 6 siswa masih kurang terampil atau masih rendah. Data tersebut menunjukan bahwa ada peningkatan dalam mengerjakan hitung penjumlahan dan pengurangan tapi belum memenuhi indikator pencapaian keberhasilan dalam penelitian, sehingga penulis melanjutkan penelitian peda siklus II untuk memperbaiki dan meningkatkan kemampuan siswa mengerjakan hitung penjumlahan dan pengurangan menjadi $90 \%$.

\section{SIKLUS II}

Dalam pelaksanaan perbaikan pembelajaran siklus II peneliti dibantu dengan teman sejawat selaku observer. pelaksanaan perbaikan pembelajaran berjalan dengan baik dan tertib. Siswa sudah mampu menggunakan media sdengan baik. Pada akhir pembelajaran peneliti mengadakan evaluasi untuk mengetahui penguasaan materi pelajaran. Dari hasil perbaikan pembelajaran siklus II dapat di ketahui peningkatan kemampuan siswa dalam mengerjakan operasi hitung penjumlahan dan pengurangan.

TABEL 2.

HASIL OBSERVASI KEMAMPUAN MENGERJAKAN OPERASI HITUNG PENJUMLAHAN DAN PENGURANGAN PADA SIKLUS II

\begin{tabular}{|c|c|c|}
\hline Prosentase & Kriteria & Jumlah Siswa \\
\hline $1 \%-20 \%$ & Sangat Rendah & - \\
\hline $21 \%-40 \%$ & Rendah & 2 \\
\hline $41 \%-60 \%$ & Cukup & 3 \\
\hline $61 \%-80 \%$ & Tinggi & 10 \\
\hline $81 \%-100 \%$ & Sangat Tinggi & 5 \\
\hline
\end{tabular}

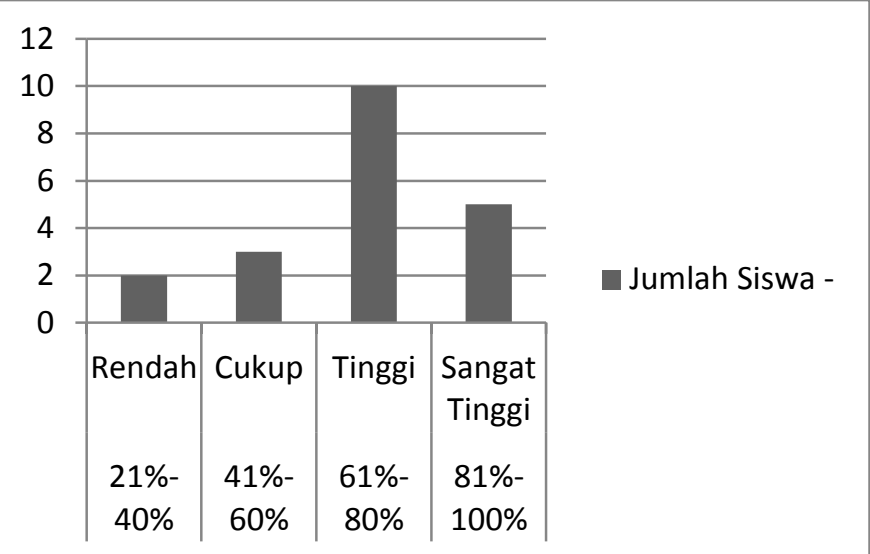

Gambar 2. Grafik Prosentase Kemampuan Mengerjakan operasi Hitung penjumlahan dan pengurangan siklus II

Berdasarkan dari hasil pengamatan di atas diketahui siswa yang kurang mampu mengerjakan hitung penjumlahan dan pengurangan ada $10 \%$, Sedangkan $90 \%$ siswa sudah mampu. Dengan demikian peningkatan kemampuan mengerjakan siswa dalam mengerjakan operasi hitung penjumlahan dan pengurangan signifikan dan dapat dikatakan berhasil. Demontrasi dengan bantuan media bau krikil kecil meningkatkan kemampuan siswa mengerjakan operasi hitung penjumlahan dan pengurangan

\section{Pembahasan}

Kegiatan pembelajaran dalam upaya untuk meningkatkan kemampuan belajar siswa kelas I SDN Aikja Kec. Praya Kabupaten Lombok Tengah dalam proses penjumlahan dan pengurangan bilangan sangat dibutuhkan metode dan media yang tepat. Menurut Sri Anitah (2009: 1) "media dapat diartikan sebagai perantara atau penghubung antara dua pihak, yaitu antara sumber pesan dengan penerima. Siswa Kelas I tidak akan berhasil dalam pembelajaran apabila hanya menghafal konsep. Perlu diingat bahwa siswa Kelas I masih identik dengan dunia bermain dan sangat memerlukan alat bantu yang nyata untuk dapat memahami konsep. Jadi alangkah baiknya bila dalam proses pembelajarannya juga menggunakan alat bantu benda-benda kongkrit . Sebelum penelitian tindakan kelas dilaksanakan peneliti dibantu beberapa guru melakukan Observasi lapangan sebagai tindakan awal. Kegiatan ini dilakukan untuk mengetahui seberapa besar tingkat ketuntasan belajar siswa dalam melakukan operasi penjumlahan dan pengurangan bilangan dalam pembelajaran Matematika. Dari kegiatan Observasi awal ini diperoleh data kemampuan siswa dalam mengerjakan hitung penjumlahan dan pengurangan masih rendah,hal ini disebabkan karena pada proses pembelajaran guru masih menggunakan metode konvensional dengan cara guru sekedar menjelaskan konsep penjumlahan dan pengurangan tanpa melaksanakan demondtrasi dengan media pembelajaran.

Dari data tersebut dapat disimpulkan bahwa operasi penjumlahan dan pengurangan bilangan belum berhasil.Kemudian peneliti mencoba untuk meningkatkan kemampuan siswa dalam mengerjakan penjumlahan dan pengurangan bilangan dengan menggunakan metode demonstrasi dan media batu krikil 
kecil karena melalui media yang nyata dapat meningkatkan kemampuan siswa dalam mengerjakan hitung. Hal ini sesuai dengan teori Bruner bahwa dalam proses belajar anak diberi kesempatan untuk memanipulasi benda atau alat peraga dan mengotak-atik alat peraga sehingga siswa akan memahami suatu konsep matematika. Oleh karena itu, guru hendaknya memanfaatkan media dalam proses belajar mengajar sehingga merangsang siswa untuk belajar dan mengoptimalkan intelektual siswa.setelah dilakukan penelitan tindakan kelas peneliti mengambil evaluasi dari masing-masing siklus dengan tujuan untuk mengetahui ada tidaknya peningkatan kemampuan siswa.

Berdasarkan observasi dengan kriteria yang sudah ditetapkan pada siklus I kemampuan siswa dalam mengerjakan operasi hitung penjumlahan dan pengurangan pada pra siklus $40 \%$ meningkat $30 \%$ menjadi $70 \%$ dan meningkat pada siklus II sebanyak $20 \%$ yaitu mencapai ]90\% .Peningkatan kemampuan siswa dalam mengerjakan operasi hitung penjumlahan dan pengurangan dapat dilihat pada grafik dibawah ini :

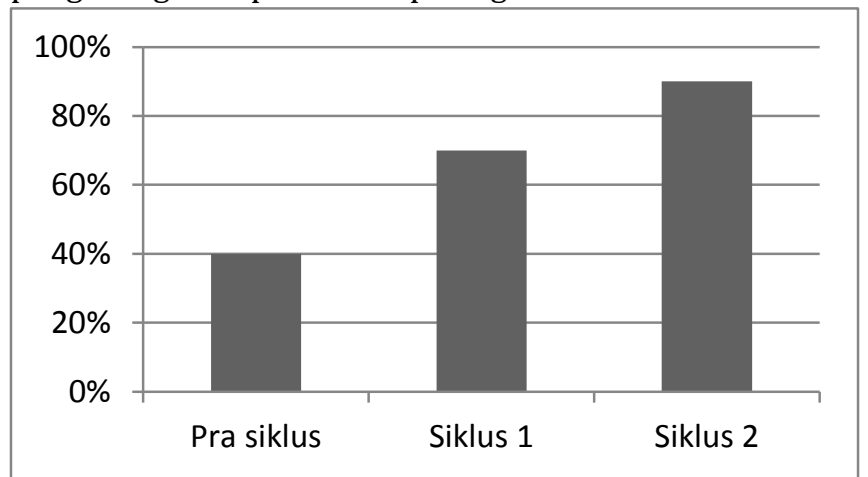

Gambar 3. Grafik Prosentase Peningkatan Kemampuan Mengerjakan Operasi Hitung Penjumlahan dan Pengurangan Melalui Metode Demonstrasi dan Media Batu Krikil Kecil

Dengan penggunaan Metode demonstrasi dan media batu krikil kecil siswa terlibat langsung dalam proses belajar mengajar, siswa dapat memanipulasi media sehingga siswa berperan aktif dalam pembelajaran untuk memahami konsep matematika dan mengembangkan keterampilan intelektualnya. Hal ini sesuai dengan teori Bruner bahwa dalam proses belajar anak diberi kesempatan untuk memanipulasi benda atau alat peraga dan mengotak-atik alat peraga sehingga siswa akan memahami suatu konsep matematika. Oleh karena itu, guru hendaknya memanfaatkan media dalam proses belajar mengajar sehingga merangsang siswa untuk belajar dan mengoptimalkan intelektual siswa. Presentase penerapan penggunaan metode demonstrasi dan media batu krikil kecil dalam penelitian ini juga mengalami peningkatan pada siklus I prosentase penerapan metode demonstrasi dan media batu krikil kecil mencapai 70\% dan meningkat pada siklus II yaitu mencapai 90\%.

Dari data kemampuan siswa dalam mengerjakan hitung penjumlahan dan pengurangan dan data penerapan metode demonstrasi dan media batu krikil kecil, dapat dinyatakan bahwa melalui metode demonstrasi dan media batu krikil kecil dapat meningkatkan kemampuan mengerjakan operasi hitung pada pembelajaran matematika materi penjumlahan dan pengurangan di kelas I SDN Aikja tahun pelajaran $2016 / 2017$.

\section{SIMPULAN DAN SARAN}

Pembelajaran yang lebih dominan sebagai pembelajaran berpusat pada guru yang bersifat konvensioanl Pembelajaran matematika sebelumnya yang digunakan adalah pembelajaran konvensional yakni ceramah, tanya jawab dan pemberian tugas sehingga pembelajaran didominasi oleh guru. Kemampuan untuk mengerjakan hitung penjumlahan dan pengurangan yang dikuasai oleh siswa masih rendah. Peneliti berusaha untuk memperbaiki pembelajaran dengan menggunakan metode demonstrasi dan pengunaan media batu krikil kecil untuk meningkatkan Kemampuan siswa dalam mengerjakan hitung penjumlahan dan pengurangan di SDN Aikja. Berdasarkan deskripsi pelaksanaan tindakan, hasil penelitian, dan pembahasan, diperoleh data adanya peningkatan kemampuan mengerjakan hitung dalam setiap siklus. Kemampuan pada pra siklus $40 \%$ meningkat $30 \%$ menjadi $70 \%$ pada siklus I dan meningkat pada siklus II sebanyak $20 \%$ yaitu mencapai $90 \%$.

Penggunaan metode demonstrasi dan media batu krikil kecil dapat menarik perhatian siswa, memperjelas pemahaman konsep penjumlahan dan pengurangan dan membuat siswa aktif dalam pembelajaran. Adanya aktifitas pembelajaran yang meningkat, suasana pembelajaran yang menyenangkan sehingga akhirnya meningkat kemampuan mengerjakan penjumlahan dan pengurangan pada siswa kelas 1 SDN Aikja.

\section{UCAPAN TERIMA KASIH}

Dengan penuh rasa hormat, saya ucapkan teimakasih kepada:

Kepala Dinas Pendidikan yang telah memfasilitasi, mengizinkan penulis untk mengadakan penelitian hingga dapat terlaksana dengan baik.

Guru-guru yang telah memberi dukungan baik secara moral maupun tindakan langsung dalam pelaksanaan penelitian ini.

\section{DAFTAR RUJUKAN}

[1] Sulikah. Peningkatan Kemampuan menghitung penjumlahan dan pengurangan menggunakan metode demonstrasi melalui media potongn batu krikil kecil pada siswa kelas 1 SDN2 Sedayu Tahun ajaran 2013/2014".Surakarta: FKIP Universitas Sebelas Maret Surakarta.

[2] Ariyanto.2011.Pembelajaran Aritmatika Sekolah Dasar. Solobaru:Qinant Joko Suwandi.2011.Penelitian Tindakan Kelas.Solobaru:Qinant

[3] Muhibbin. 2004. Strategi Pembelajaran Matematika. Semarang: LPMP Jawa Tengah

[4] Mulyono. 2003. Pendidikan Bagi Anak Berkesulitan Belajar. Jakarta: Depdikbud dan Rineka Cipta.

[5] Rubino Rubiyanto.2011.Metode Penelitian Pendidikan. Solobaru:Qinant

[6] Ruseffendi, ET. 1989. Dasar-Dasar Matematika Modern dan Komputer Untuk Guru. Bandung: Tarsito.

[7] Sri Hartini.2011.Evaluasi Pembelajaran. Solobaru:Qinant

[8] Tim Penyusun Kamus Pusat Bahasa. 2002. Kamus Besar Bahasa Indonesia. Jakarta: BaLai Pustaka. 